\title{
KEMAMPUAN REPRESENTASI MATEMATIS DALAM MATERI FUNGSI DENGAN PENDEKATAN OPEN ENDED PADA SISWA KELAS VIII MTS SIRAJUL ULUM PONTIANAK
}

\author{
Hartono $^{1}$, Muhamad Firdaus ${ }^{2}$, Sipriyanti ${ }^{3}$ \\ ${ }^{1,2,3}$ Program Studi Pendidikan Matematika, IKIP PGRI Pontianak \\ Email: andra.hartono@gmail.com
}

\begin{abstract}
The purpose of this study was to determine the ability of mathematical representation through an open-ended approach to functional material in class VIII MTs. Sirajul Ulum Pontianak. The research method used was the experimental method with Quasi experimental research and the design used in this study was posttest-only control design. The results obtained were (1) the average ability of students' mathematical representation after being taught with an open-ended approach was 72 with the criteria classified as good; (2) The average mathematical representation ability of students is 57 with criteria classified as sufficient; and (3) The ability of mathematical representations given to the treatment of open-ended approaches is better than students given the treatment of conventional learning models, this can be seen from the average results and has been proven using inferential statistics. Every student in the control class or experiment experiences problems on each indicator, which is what distinguishes the average.
\end{abstract}

Keyword: Mathematical Representation, Open Ended Approach, Function

\section{PENDAHULUAN}

Matematika merupakan salah satu mata pelajaran yang diberikan di seluruh sekolah atau dunia pendidikan, mulai dari pendidikan dasar hingga perguruan tinggi. Matematika merupakan ilmu yang berkaitan erat dengan kehidupan sehari-hari bahkan matematika sebagai dasar untuk mempelajari ilmu-ilmu yang lain. Pendidikan matematika di sekolah dapat mempersiapkan siswa agar dapat menggunakan matematika dengan fungsional, baik dalam kehidupan sehari-hari maupun dalam ilmu pengetahuan lain. Oleh sebab itu, sudah semestinya matematika diajarkan sedini mungkin pada setiap siswa.

Sampai saat ini mata pelajaran matematika masih saja dianggap susah dan sulit untuk dipelajari dan dipahami oleh siswa meskipun tidak semuanya beranggapan seperti itu. Kenyataan seperti itu terjadi dikarenakan banyak siswa yang gaya belajarnya dengan cara menghapal dan melihat saja. Tanpa mereka sadari bahwa setiap soal akan berbeda-beda jenisnya. Seharusnya siswa bisa mengkaji dan memahami apa yang dipelajarinya tanpa harus mendengar informasi. Banyak 
penyebab siswa sulit dalam mempelajari matematika. Hal utama yang menyebabkan, yaitu aspek kognitif dalam pembelajaran matematika.

Berdasarkan hasil wawancara peneliti dengan salah satu guru matematika MTs. Sirajul Ulum Pontianak pada tanggal 21 Agustus 2017 bahwa pembelajaran masih cenderung berpusat kepada guru. Pembelajaran masih bersifat mentransfer informasi semata dengan model pembelajaran konvensional yang menggunakan metode ceramah, tanya jawab serta pemberian tugas sehingga kurang bermakna bagi para siswa. Saat wawancara berlangsung guru tersebut mengatakan bahwa siswa masih sering mengalami kesulitan pada kemampuan-kemampuan matematis, termasuk pada kemampuan representasi matematis.

Setelah melakukan wawancara dengan guru, peneliti langsung memberikan soal kepada siswa. Soal yang diberikan tentang materi fungsi. Dengan soal tersebut, peneliti ingin melihat langsung kemampuan representasi matematis siswa. Soal yang diberikan adalah "Relasi dari himpunan $\mathrm{P}=\{1,3,5,7\}$ ke himpunan $\mathrm{Q}=$ $\{a, b, c, d\}$ dinyatakan dalam himpunan pasangan berurutan berikut:
a) $\{(1, a)(3, b)(5, c)(5, d)\}$;
b) $\{(1, d)(3, a)(5, c)(7, d)\}$;
c) $\{(1, a)(1, b)(1, c)(1, d)\}$;

d) $\{(1, a)(3, a)(5, a)(7, a)\}$.

Di antara keempat relasi di atas, manakah yang merupakan fungsi? Jelaskan pendapat anda dengan membandingkan relasi lainnya dengan yang bukan merupakan fungsi!

Terlihat dari jawaban siswa tersebut bahwa kemampuan representasinya masih kurang. Siswa hanya menentukan fungsinya saja, tetapi tidak memberikan alasannya. Melihat jawaban siswa yang tidak bisa merepresentasikan soal ke jawaban maka peneliti lebih tertarik untuk melihat kemampuan representasi matematis. Jawaban siswa dapat dilihat pada gambar berikut ini.

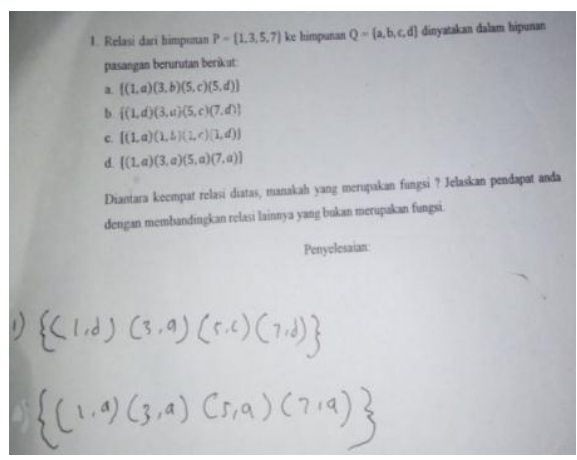

\section{Gambar 1} Jawaban siswa

Oleh karena itu, peneliti mengangkat kemampuan representasi matematis sebagai masalah utama dalam penelitian ini. Meskipun kemampuan representasi matematis selalu melekat dalam pembelajaran matematika, masih banyak guru yang tidak menyadari manfaatnya, khususnya bagi guru-guru mata pelajaran matematika. 
Kemampuan berupa keterampilan untuk memanfaatkan representasi yang dimiliki siswa harus ditanamkan atau diajarkan sedini mungkin. Kebiasaan cara belajar klasikal maupun kelompok yang kurang bermakna serta strategi, model dan pendekatan pembelajaran yang tidak bermakna menjadi penyebab peserta didik sulit untuk mengembangkan kemampuan representasinya.

Berkaitan dengan tujuan pembelajaran matematika, Afandi (NCTM, 2000:7) menyatakan bahwa ada lima lima standar proses pembelajaran matematika, yaitu pemecahan masalah (problem solving), penalaran dan bukti (reason and proof), komunikasi (communication), koneksi (connections), dan representasi (representation). Berdasarkan standar pembelajaran tersebut kemampuan representasi matematis merupakan faktor yang sangat penting dalam proses pembelajaran matematika. Jika setiap siswa memiliki kemampuan representasi matematis, besar kemungkinan siswa akan mampu menyelesaikan setiap permasalahan matematika, baik dalam proses belajar mengajar maupun dalam kehidupan nyata.

Kemampuan representasi matematis adalah kemampuan yang dimiliki dalam menyajikan kembali gambar, tabel, grafik, simbol, notasi, diagram, persamaan atau ekspresi matematis serta kata-kata/teks tertulis ke dalam bentuk yang lain. Syafri
(2017: 51) menyatakan bahwa kemampuan representasi matematis merupakan suatu kemampuan matematika dengan pengungkapan ide-ide matematika (masalah, pernyataan, definisi, dan lain-lain) dalam berbagai cara. Pendekatan open-ended adalah pendekatan pembelajaran dengan menyajikan suatu permasalahan kepada siswa yang memiliki lebih dari satu jawaban atau metode penyelesaian (masalah terbuka) dan siswa bebas memilih cara penyelesaian. Dalam proses pembelajaran siswa dihadapkan dengan berbagai masalah. Siswa dituntut untuk dapat menyelesaikan soal tersebut dengan mengembangkan metode, cara atau pendekatan yang berbeda-beda. Siswa tidak hanya diminta untuk menemukan jawaban yang benar saja, tetapi juga siswa harus bisa menjelaskan bagaimana cara yang telah ditempuh sehingga bisa menghasilkan jawaban yang benar .

Pendekatan open-ended merupakan pendekatan yang memberikan kesempatan/keleluasaan kepada siswa untuk mengembangkan kemampuan, pengetahuan, pengalaman, menemukan dan mengenali karena setiap soal yang diberikan, siswa bebas memilih cara yang tepat untuk digunakan. Sari dkk. (2013:11) mengatakan bahwa pendekatan open-ended menjanjikan suatu kesempatan kepada siswa untuk menginvestigasi berbagai cara yang diyakininya sesuai dengan kemam- 
puan mengelaborasi permasalahan. Melalui pendekatan open-ended, siswa dituntut untuk melakukan observasi, bertanya, menentukan relasi mengungkapkan ide-ide dan menarik kesimpulan. Oleh karena itu, pendekatan open-ended memiliki banyak kesesuaian dengan kemampuan representasi matematis.

Pendekatan open-ended tidak hanya memberi hasil akhir saja, tetapi juga para siswa dituntut untuk mengembangkan kreativitasnya dalam mengungkapkan ideide atau wawasan mengenai masalah yang diberikan. Pendekatan open-ended juga dapat memberikan kesempatan kepada siswa untuk memperoleh pengetahuan ataupun pengalaman dalam proses penyelesaian masalah. Pendekatan openended tidak hanya menekankan pada siswa untuk memiliki kemampuan berhitung saja, tetapi juga kemampuan menyelesaikan soal matematika. Pendekatan tersebut juga menekankan kemampuan siswa menerapkan serta menyelesaikan masalah matematika yang dihadapinya dalam pendidikan ataupun kehidupan sehari-hari. Adapun hipotesis dalam penelitian ini, yaitu kemampuan representasi matematis yang diberikan kepada siswa dengan pendekatan open-ended lebih baik daripada siswa yang diberikan model pembelajaran konvensional dalam materi fungsi pada siswa kelas VIII MTs. Sirajul Ulum Pontianak.

\section{KAJIAN TEORI}

\section{Kemampuan Representasi}

Menurut Lestari \& Yudhanegara (2017:83) bahwa kemampuan representasi adalah kemampuan menyajikan kembali notasi, simbol, tabel, gambar, grafik, diagram, persamaan atau ekspresi matematis lainnya ke dalam bentuk lain. Representasi yang dimunculkan oleh siswa merupakan ungkapan-ungkapan dari gagasan-gagasan atau ide-ide matematis yang ditampilkan siswa dalam upayanya untuk mencari suatu solusi dari masalah yang sedang dihadapinya. Menurut Syafri (Goldin, 2002), representasi merupakan suatu konfigurasi yang bisa merepresentasikan sesuatu yang lain dalam beberapa cara. Susanto (dalam Dianti, 2015:13) mengartikan representasi adalah bentuk baru dari hasil translasi suatu masalah atau ide, atau tanslasi suatu diagram dari model fisik ke dalam simbol atau kata-kata. Effendi (2012) menetapkan bahwa program pembelajaran dari prataman kanak-kanak sampai kelas 12 harus memungkinkan siswa untuk: (1) menciptakan dan menggunakan representasi untuk mengorganisasi, mencatat, dan mengomunikasikan ide-ide matematis; (2) memilih, menerapkan, dan menerjemahkan representasi matematis untuk memecahkan masalah; dan (3) menggunakan representasi untuk memodelkan dan menginterpretasikan fe- 
nomena fisik, sosial, dan fenomena matematis.

Ditinjau dari mana representasi itu muncul, terdapat tiga jenis representasi yaitu: internal, eksternal, dan internaleksternal atau representasi bersama (shared representation). Repesentasi eksternal dapat merupakan tanda, karakter, atau objek yang dihasilkan mahasiswa sebagai produk, tetapi tidak dikonstruksi mahasiswa. Representasi internal yang disebut juga representasi psikologis berkaitan dengan perilaku mahasiswa terhadap konsep matematika (Goldin dan Shteingold dalam Dewanto, 2008).

Ada beberapa pengertian representasi menurut beberapa ahli (Fadillah dalam Dianti, 2015:12) diantaranya adalah sebagai berikut.

1) Representasi adalah model atau bentuk pengganti dari suatu situasi masalah atau aspek dari suatu situasi masalah yang digunakan untuk menemukan solusi. Sebagai contoh, suatu masalah dapat direpresentasikan dengan objek, gambar, kata-kata, atau simbol matematika.

2) Representasi merupakan cara yang digunakan seseorang untuk mengomunikasikan jawaban atau gagasan matematik yang bersangkutan.

3) Representasi adalah suatu konfigurasi yang dapat menyajikan suatu benda dalam suatu cara.
4) Dalam psikologi umum, representasi berarti proses membuat model konkret dalam dunia nyata ke dalam konsep abstrak atau simbol. Dalam psikologi matematika, representasi bermakna deskripsi hubungan antara objek dengan simbol.

Dapat dilihat bahwa istilah representasi menunjuk proses pemindahan representasi kebentuk yang lain, bagaimana cara pemindahannya dan bagaimana hasil pemindahan representasi tersebut. Selain itu, dalam pembelajaran tersebut kemampuan representasi yang dikembangkan memiliki kecenderungan dalam bentuk translasi dari deskripsi verbal yang biasanya berbentuk soal cerita diubah ke dalam bentuk representasi lain seperti: simbol, grafik atau tabel, dan jarang terjadi sebaliknya (Hudiono, 2007:3). Simpulan representasi matematis adalah ungkapanungkapan ide dan gagasan matematis yang yang ditampilkan siswa atau bentuk pengganti dari suatu masalah yang sedang dihadapinya sebagai hasil dari interprestasi pikirannya.

Menurut Jones (Hudiono, 2007) terdapat beberapa alasan penting dimasukkannya standar proses representasi, yaitu:

1) kelancaran dalam melakukan translasi di antara berbagai bentuk representasi berbeda, merupakan kemampuan mendasar yang perlu dimiliki siswa untuk 
membangun suatu konsep dan berpikir matematika;

2) cara ide-ide matematika yang disajikan guru melalui berbagai representasi akan memberikan pengaruh yang sangat besar terhadap pemahaman siswa dalam mempelajari matematika;

3) siswa membutuhkan latihan dalam membangun representasinya sendiri sehingga memiliki kemampuan dan pemahaman konsep yang kuat dan fleksibel yang dapat digunakan dalam memecahkan masalah.

Representasi juga merupakan bagian dari komunikasi matematis yang dapat berbentuk seperti bahasa biasa. Bahasa tersebut merupakan bahasa verbal, bahasa simbol, bahasa visual, dan bahasa kuasimatematis. Beberapa jenis bahasa di atas dapat berfungsi untuk menyalurkan ide-ide atau gagasan matematis. Dapat disimpulkan bahwa kemampuan representasi adalah kemampuan yang dimiliki seseorang/siswa dalam menentukan solusisolusi dari setiap masalah yang ada dengan berbagai bentuk matematis seperti, representasi verbal (kata-kata atau teks tertulis), representasi visual (gambar, grafik, dan diagram), serta representasi simbolik (pernyataan matematis atau simbol-simbol matematika).

Berdasarkan pendapat di atas dapat disimpulkan bahwa representasi matematis merupakan kemampuan siswa dalam mengungkapkan ide ataupun gagasan matematika melalui cara-cara tertentu. Kemampuan representasi matematis adalah kemampuan yang dimiliki siswa dalam mengubah masalah matematika kebentuk yang lain karena kemampuan representasi merupakan salah satu kunci kemampuan komunikasi matematis.

Adapun indikator kemampuan representasi matematis menurut Lestari \& Yudhanegara (2017) disajikan pada Tabel 1.

Tabel 1

Indikator kemampuan representasi matematis

\begin{tabular}{|c|c|}
\hline Aspek & Indikator \\
\hline $\begin{array}{c}\text { Representasi } \\
\text { Visual }\end{array}$ & $\begin{array}{l}\text { a. Menyajikan kembali data } \\
\text { atau informasi dari suatu } \\
\text { representasi ke representasi } \\
\text { diagram, grafik, atau tabel } \\
\text { b. Menggunakan representasi } \\
\text { visual untuk penyelesaian } \\
\text { masalah. }\end{array}$ \\
\hline $\begin{array}{c}\text { Representasi } \\
\text { Gambar }\end{array}$ & $\begin{array}{l}\text { a. Membuat gambar pola-pola } \\
\text { geometri. } \\
\text { b. Membuat gambar bangun } \\
\text { geometri untuk } \\
\text { memperjelas masalah dan } \\
\text { memfasilitasi masalah. }\end{array}$ \\
\hline $\begin{array}{l}\text { Representasi } \\
\text { Persamaan } \\
\text { atau Ekspresi } \\
\text { Matematis }\end{array}$ & $\begin{array}{ll}\text { a. } & \text { Membuat persamaan atau } \\
\text { model matematis dari } \\
\text { representasi lain yang } \\
\text { diberikan. } \\
\text { b. Membuat konjektur dari } \\
\text { suatu pola bilangan. } \\
\text { c. Penyelesaian masalah } \\
\text { dengan melibatkan ekspresi } \\
\text { matematis. }\end{array}$ \\
\hline $\begin{array}{c}\text { Representasi } \\
\text { Kata atau Teks } \\
\text { Tertulis }\end{array}$ & $\begin{array}{l}\text { a. Membuat situasi masalah } \\
\text { berdasarkan data atau } \\
\text { representasi yang diberikan. } \\
\text { b. Menulis interprestasi dari } \\
\text { suatu representasi. } \\
\text { c. Menulis langkah-langkah } \\
\text { penyelesaian masalah } \\
\text { dengan kata-kata. } \\
\text { d. Menjawab soal dengan } \\
\text { menggunakan kata-kata } \\
\text { atau teks tertulis. }\end{array}$ \\
\hline
\end{tabular}


Menurut NCTM (2000) representasi memiliki indikator yang harus diperhatikan, yaitu sebagai berikut. Pertama, menggunakan berbagai representasi matematis untuk menjelaskan ide-ide matematis; Kedua, melakukan translasi antar representasi matematis; Ketiga, menginterpretasikan fenomena matematis dengan berbagai representasi matematis; dan Keempat, representasi matematis terdiri atas: visual (grafik, diagram, tabel atau gambar), simbolik (pernyataan matematis/notasi matematis. Dalam penelitian ini tidak semua aspek kemampuan representasi matematis diukur, melainkan hanya sebagian indikatornya saja. Adapun indikator yang dipakai pada penelitian ini adalah 1) menjawab soal dengan menggunakan kata-kata atau teks tertulis 2) menulis langkah-langkah penyelesaian dengan kata-kata 3) menulis interprestasi dari suatu representasi, indikator 1-3 tersebut tergolong pada aspek representasi kata atau teks tertulis dan 4) menyajikan kembali data atau informasi dari suatu representasi ke representasi diagram, grafik atau tabel, untuk indikator yang keempat terdapat pada aspek representasi visual.

\section{METODOLOGI PENELITIAN}

Tujuan dalam penelitian ini adalah untuk mengetahui kemampuan representasi matematis melalui pendekatan open-ended dalam materi fungsi pada siswa kelas VIII
MTs. Sirajul Ulum Pontianak. Metode penelitian yang digunakan metode eksperimen dengan bentuk penelitian Quasi experimental serta Rancangan yang digunakan dalam penelitian ini adalah posttest-only control design. Populasi dalam penelitian ini adalah siswa kelas VIII MTs. Sirajul Ulum Pontianak, yaitu kelas VIII A dan VIII B, sedangkan pengambilan sampel menggunakan sampling jenuh dengan kelas VIII A sebagai kelas eksperimen dan kelas yang lain sebagai kelas kontrol. Teknik pengumpul data dalam penelitian ini adalah dengan pengukuran yaitu alat yang digunakan berupa tes kemampuan representasi. Teknik dan analisis data dengan langkah-langkah perhitungan sebagai berikut:

1. Memberikan skor hasil tes siswa berdasarkan pedoman penskoran.

2. Memberikan skor pada tiap butir soal dengan ri Nilai $=\frac{\text { skor yang diperoleh }}{\text { skor total }} \times 100$

3. Mencari skor rata-rata (x bar) dengan rumus

$$
\bar{X}=\frac{\sum x}{N}
$$

Keterangan:

$\bar{X} \quad=$ rata-rata nilai

$\boldsymbol{\Sigma} \chi=$ jumlah nilai

$N$ = banyaknya data

Dengan kriteria sebagai berikut:

80 - 100 adalah baik sekali

66 - 79 adalah baik

56 - 65 adalah cukup 
40 - 55 adalah kurang

30 - 39 adalah gagal

(Arikunto, 2010:245).

Untuk menguji hipotesis dilakukan perhitungan sebagai berikut:

1. Menguji normalitas skor post-test kelompok eksperimen dan kontrol. Menurut Subana dkk (2000:176) untuk mengetahui apakah data yang kita miliki normal atau tidak secara konfirmatif (inferensial) maka akan kita gunakan rumus kai kuadrat (chi square) sebagai berikut:

$$
\begin{aligned}
& \chi^{2}=\frac{\left(f_{01}-f_{h 1}\right)}{f_{h 1}}+\frac{\left(f_{02}-f_{h 2}\right)}{f_{2}} \\
& \chi^{2}=\frac{\sum\left(f_{0}-f_{h}\right)^{2}}{f_{h}}
\end{aligned}
$$

\section{Keterangan:}

$f_{0}=$ frekuensi observasi

$f_{h}=$ frekuensi harapkan (ekspektasi)

Menentukan normalitas:

Jika $\chi^{2}$ hitung $<\chi^{2}$ tabel, populasi berdistribusi normal

Jika $\chi^{2}$ hitung $>\chi^{2}$ tabel, populasi tidak berdistribusi normal

2. Jika ternyata kedua berdisribusi normal, dilanjutkan dengan uji homogenitas variansinya, yaitu uji $\mathrm{F}$ (Sugiyono, 2016: 197).

$$
F=\frac{\text { Varians terbesar }}{\text { Varians terkecil }}
$$

Penentuan homogenitas:

Jika $F$ hitung $<F$ tabel, kedua variansi tersebut homogen

Jika $F$ hitung $>F$ tabel, kedua variansi tersebut tidak homogen

3. Jika keduanya berdistribusi normal dan kedua variansinya homogen, dilakukan Uji-t polled varians (Sugiyono, 2016:197). Langkah-langkah Uji-t yang digunakan adalah sebagai berikut:

$$
t=\frac{\bar{x}_{1}-\bar{x}_{2}}{\sqrt{\frac{\left(n_{1}-1\right) s_{1}^{2}+\left(n_{2}-1\right) s_{2}^{2}}{n_{1}+n_{2}-2}\left[\frac{1}{n_{1}}-\frac{1}{n_{2}}\right]}}
$$

Keterangan:

$\bar{x}_{1}=$ rata-rata skor kelompok 1

$\bar{x}_{2}=$ rata-rata skor kelompok 2

$n_{1}=$ jumlah sampel kelompok 1

$n_{2}=$ jumlah sampel kelompok 2

$s_{1}=$ variansi kelompok 1

$s_{2}=$ variansi kelompok 2

Dengan kriteria pengujian:

$H_{O}$ ditolak jika $t_{\text {hitung }}>t_{\text {tabel }}$ dan

$H_{O}$ diterima jika $t_{\text {hitung }} \leq t_{\text {tabel }}$

4. Jika keduanya berdistribusi normal dan variansnya tidak homogen, .akan dianalisis dengan Uji-t separated varians (Sugiyono, 2016:197). Dengan rumus sebagai berikut:

$$
t=\frac{\bar{x}_{1}-\bar{x}_{2}}{\sqrt{\frac{s_{1}^{2}}{n_{1}}+\frac{s_{2}^{2}}{n_{2}}}}
$$


Keterangan:

$\bar{x}_{1}=$ rata-rata skor kelas eksperimen

$\bar{x}_{2}=$ rata-rata skor kelas kontrol

$s_{1}=$ varians kelas eksperimen

$s_{2}=$ varians kelas kontrol

$n_{1}=$ jumlah data kelas eksperimen

$n_{2}=$ jumlah data kelas kontrol

Dengan kriteria uji

$H_{O}$ ditolak jika $t_{\text {hitung }}>t_{\text {tabel }}$ dan

$H_{O}$ diterima jika $t_{\text {hitung }} \leq t_{\text {tabel }}$

5. Jika ternyata salah satu atau kedua kelompok tidak berdistribusi normal, langkah selanjutnya menggunakan statistik nonparametrik, yaitu uji $\mathrm{U}$ Mann-Whitney (Lestari \& Yudhanegara, 287).

$$
Z_{\text {hitung }}=\frac{\sum \mathrm{R}\left(\mathrm{X}_{1}\right)-n 1\left(\frac{N+1}{2}\right)}{\sqrt{\frac{n_{1} \cdot n_{1}}{N(N-1)} \cdot\left[\sum R\left(X_{1}\right)^{2}+\sum R\left(X_{2}\right)^{2}\right]-\frac{n_{1} n_{2} \cdot(N+1)^{2}}{4(N-1)}}}
$$

Keterangan:

$$
\begin{array}{ll}
\mathrm{R}\left(\mathrm{X}_{1}\right) & =\text { Rank untuk } \mathrm{X}_{1} \\
\mathrm{R}\left(\mathrm{X}_{2}\right) & =\text { Rank untuk } \mathrm{X}_{2} \\
\mathrm{~N} & =\mathrm{n}_{1}+\mathrm{n}_{2}
\end{array}
$$

\section{HASIL PENELITIAN}

Dari hasil pengumpulan data selama proses penelitian berlangsung di MTs Sirajul Ulum Pontianak yang diperoleh dari dua kelas yang diambil, yaitu kelas VIII A sebagai kelas eksperimen ada 15 siswa dan kelas VIII B sebagai kelas kontrol ada 14 siswa. Didapat data dari hasil posttest setelah diberikan perlakuan, yaitu dengan menggunakan pendekatan open-ended dan model pembelajaran konvensional pada materi fungsi. Data yang diperoleh tersaji dalam tabel 2.

Tabel 2

Rangkuman hasil posttest

\begin{tabular}{cllll}
\hline Posttest & \multicolumn{2}{l}{ Kelas Eksperimen } & \multicolumn{2}{l}{ Kelas Kontrol } \\
\cline { 2 - 5 } & Rata- & SD & Rata- & SD \\
& Rata & Nilai & Rata & Nilai \\
& Nilai & & Nilai & \\
\cline { 2 - 5 } & 72,133 & 14,5733 & 57,7857 & 14,52 \\
& & & 94 \\
\hline
\end{tabular}

Data dari hasil perhitungan di atas dapat disimpulkan bahwa rata-rata hasil kemampuan representasi matematis siswa yang diajarkan menggunakan pendekatan open-ended pada rata-rata posttest tergolong baik, yaitu sebesar $(72,133)$ dan hasil belajar siswa yang menggunakan model pembelajaran konvensional pada rata-rata posttest tergolong cukup yaitu sebesar $(57,7857)$.

a) Uji normalitas data kelompok eksperimen menggunakan rumus chi square.

Jika $\mathrm{x}^{2}$ hitung $<\mathrm{x}^{2}$ tabel, data berdistribusi normal. Namun jika $\mathrm{x}^{2}$ hitung $>\mathrm{x}^{2}$ tabel, data tidak berdistribusi normal. Berdasarkan hasil uji normalitas posttest diperoleh nilai $\mathrm{x}^{2}$ hitung $<\mathrm{x}^{2}$ tabel atau $-0,60<5,99$ maka dapat disimpulkan bahwa data berdistribusi normal.

b) Uji normalitas data kelompok kontrol menggunakan rumus chi kuadrat

Jika $\mathrm{x}^{2}$ hitung $<\mathrm{x}^{2}$ tabel, data berdistribusi normal. Namun jika $\mathrm{x}^{2}$ hitung $>\mathrm{x}^{2}$ tabel, data tidak berdistribusi 
normal. Berdasarkan hasil uji normalitas posttest diperoleh nilai $\mathrm{x}^{2}$ hitung $<\mathrm{x}^{2}$ tabel atau 5,21 $<5,99$ maka dapat disimpulkan bahwa data berdistribusi normal.

c) Uji homogenitas menggunakan uji $\mathrm{F}$

Sampel dalam penelitian ini sebanyak dua kelas maka untuk menguji kesamaan rata-rata variansvariansnya digunakan uji $F$. jika $F^{2}$ hitung $<\mathrm{F}^{2}$ tabel, data tersebut homogen. Namun, jika $F^{2}$ hitung $>F^{2}$ tabel, datanya tidak homogen. Berdasarkan hasil perhitungan yang menggunakan uji $\mathrm{F}$ diperoleh nilai $\mathrm{F}_{\text {hitung }}<\mathrm{F}$ tabel atau 1,29 $<2,53$ maka dapat dinyatakan bahwa kedua varians homogen.

\section{d) Analisis Data Hasil Uji Hipotesis}

Berdasarkan data di atas diperoleh hasil bahwa data kelas berdistribusi normal maka dapat dilanjutkan dengan pengujian hipotesis dengan menggunakan statistik parametrik dengan uji $\mathrm{t}$ polled varians. Taraf signifikan $(\alpha)$ yang digunakan adalah 5\% dengan kriteria pengujian jika $\mathrm{t}^{2}$ hitung $>\mathrm{t}^{2}$ tabel maka $\mathrm{H}_{0}$ ditolak (dalam keadaan lain Ha). Berdasarkan perhitungan diperoleh $\mathrm{t}^{2}$ hitung $>\mathrm{t}^{2}$ tabel atau 2,73> 1,70 maka $\mathrm{H}_{0}$ ditolak pada taraf signifikan $5 \%$ dan ini berarti bahwa $\mathrm{H} \alpha$ diterima. Hal ini me- nunjukkan bahwa pendekatan openended lebih baik daripada model pembelajaran konvensional.

\section{PEMBAHASAN}

Nilai rata-rata posttest siswa kelas eksperimen sebesar 72,133 dengan kriteria baik. Peneliti melihat untuk kelas eksperimen bahwa ternyata siswa masih kesulitan pada indikator menulis interprestasi dari suatu representasi, yaitu para siswa masih mengalami kesulitan untuk menjelaskan apa yang telah mereka lihat. Tampak dari hasil jawaban siswa, mereka masih kurang pandai dalam berkata-kata. Padahal melalui gagasan-gagasan yang mereka tampilkan menurut Afandi (2013) dengan demikian diharapkan bahwa bilamana siswa memiliki akses ke representasi dan gagasan-gagasan yang mereka tampilkan, siswa memiliki sekumpulan alat yang siap secara signifikan akan memperluas kapasisitas siswa dalam berpikir matematis.

Nilai rata-rata posttest siswa kelas kontrol sebesar 57,786 dengan kriteria cukup. Kesulitan pada kelas kontrol juga pada beberapa indikator yang pertama menulis langkah-langkah penyelesaian dengan kata-kata. Sebagian siswa masih mengalami kesulitan menuliskan langkah-langkah pengerjaannya dengan kata-kata, dapat dilihat dari jawaban siswa. Kedua menjawab soal dengan menggunakan kata-kata atau teks tertulis, permasalahan kedua 
siswa mengalami kesulitan pada saat memberikan penjelasan. Terakhir yang ketiga menulis interprestasi dari suatu representasi.

Dapat disimpulkan bahwa pendekatan open-ended dapat meningkatkan kemampuan representasi matematis siswa. Sejalan dengan yang diungkapkan Afandi (2013:60) bahwa pendekatan open-ended lebih efektif dibandingkan pendekatan inkuiri terbimbing terhadap kemampuan reepresentasi multiple matematis siswa. Hal ini juga didukung oleh pendapat Muhsinin (2013:58). Dia mengatakan bahwa pembelajaran open-ended adalah pembelajaran yang menyajikan masalah terbuka, yakni masalah matematika yang memiliki metode atau cara penyelesaian lebih dari satu dan jawaban benar lebih dari satu.

Berdasarkan hasil uji-t diperoleh $\mathrm{t}$ hitung $>t_{\text {tabel }}$ atau 2,73>1,70, maka $\mathrm{H}_{0}$ ditolak pada taraf signifikan $5 \%$ dan ini bearti bahwa $\mathrm{H} \alpha$ diterima. Dapat disimpulkan bahwa terdapat perbedaan kemampuan representasi matematis siswa yang diterapkan dengan pendekatan openended dengan yang diterapkan model pembelajaran konvensional, Dalam penelitian ini, pendekatan open-ended digunakan untuk meningkatkan kemampuan representasi matematis siswa pada materi fungsi. Hasil penelitian tersebut juga sejalan dengan penelitian relevan yang dilakukan oleh (Wahyudi T, 2015) menyatakan bahwa secara marginal siswa dengan pendekatan open-ended memberikan hasil belajar lebih baik daripada konvensional, baik pada siswa dengan kemampuan awal matematika tinggi, sedang, dan rendah. Dengan demikian, selama dengan pembelajaran pendekatan open-ended terdapat peningkatan yang cukup signifikan antara skor nilai posttest kelas eksperimen dan kelas kontrol MTs Sirajul Ulum Pontianak.

Adapun faktor-faktor yang menjadi sebab terdapatnya peningkatan kemampuan representasi matematis siswa setelah diajarkan dengan pendekatan open-ended pada materi fungsi adalah sebagai berikut:

1. Dalam pembelajaran dengan pendekatan open-ended siswa mendapat motivasi supaya dapat saling mendukung dan membantu satu sama lain antar kelompok.

2. Adanya pendekatan open-ended dapat membantu dan membimbing siswa saat mengerjakan soal menjelaskan atau membantu siswa dalam melakukan komunikasi dengan sesama teman atau dengan guru.

\section{SIMPULAN}

Berdasarkan hasil pengolahan data penelitian secara umum dapat disimpulkan bahwa kemampuan representasi matematis siswa setelah diajarkan dengan pendekatan open-ended lebih baik pada materi fungsi di kelas VIII MTs Sirajul Ulum Pontianak. 
1. Rata-rata kemampuan representasi matematis siswa setelah diajarkan dengan pendekatan open-ended adalah 72,1333 dengan kriteria tergolong baik pada materi fungsi. Hal tersebut terlihat jelas dari hasil kerja siswa yang peneliti dapat dari tes kemampuan representasi matematis.

2. Rata-rata kemampuan representasi matematis siswa adalah 57,7857 dengan kriteria tergolong cukup pada materi fungsi setelah diajarkan dengan model pembelajaran konvensional terlihat dari hasil hitung rata-rata dengan menggunakan model tersebut.
3. Kemampuan representasi matematis yang diberikan perlakuan pendekatan open-ended lebih baik daripada siswa yang diberikan perlakuan model pembelajaran konvensional hal tersebut dapat dilihat dari hasil rata-rata dan telah dibuktikan menggunakan statistik inferensial. Setiap siswa dikelas kontrol ataupun eksperimen mengalami masalah pada tiap indikator soal hal tersebutlah yang membedakan rataratanya.

\section{DAFTAR RUJUKAN}

Afandi A. 2013. Pendekatan Open-ended dan Inkuiri Terbimbing ditinjau dari Kemampuan Pemecahan Masalah dan Representasi Multipel Matematis. Jurnal Pendidikan Matematika Vol. 8, No.1 (Online) 05 September 2017.

2014. Perbandingan Pendekatan Open-Ended dan Inkuiri Terbimbing Ditinjau dari Kemampuan Pemecahan Masalah dan Representasi Multipel Matematis. Jurnal Vol. 3, No. 1 (Online) Diakses 05 Agustus 2017.

Arikunto, S. 2010. Dasar-Dasar Evaluasi Pendidikan. Jakarta: PT Bumi Aksara.

Dewanto S. 2008. Peranan Kemampuan Akademik Awal, Self-Efficacy, dan Variabel Nonkognitif Lain Terhadap Pencapaian Kemampuan Represen- tasi Multipel Matematis Mahasiswa Melalui Pembelajaran Berbasis Masalah.Vol. II No. 2 (Online) Diakses 05 September 2017.

Dianti R. 2015. Meningkatkan Kemampu- an Representasi Matematis Siswa Melalui Model Problem Based Learning (PBL) pada Materi Persamaan Garis Lurus. Skripsi Sarjana IKIP-PGRI Pontianak: Tidak Diterbitkan.

Effendi L. 2012. Pembelajaran Matema- tika Dengan Metode Penemuan Terbimbing Untuk Meningkatkan Kemampuan Representasi dan Pemecahan Masalah Matematis Siswa SMP. Jurnal Penelitian Pendidikan Vol. 13 No. 2 (Online) 08 Agustus 2017. 
Hudiono B. 2007. Representasi Dalam Pembelajaran Matematika. Pontianak: STAIN Pontianak Press.

Lestari \& Yudhanegara. 2017. Penelitian Pendidikan Matematika.Bandung: PT Refika Aditama.

Muhsinin U. 2013 Pendekatan Open-Ended Pada Pembelajaran Matematika. Edu-Math; Vol. 4 (Online) 05 September 2017.

National Council of Teacher of Mathematics (NCTM).(2000). Principles and Standards for School Mathematics. (NCTM): USA.

Sari Y. dkk. 2013. Penerapan Pendekatan Open-Ended dalam Pembelajaran Matematika untuk Meningkatkan Kemampuan Berpikir Matematis Siswa ditinjau dari Respon Siswa Terhadap Pembelajaran. Jurnal Pendidikan Matematika Solusi Vol. 1 No. 1 (Online) 08 Agustus 2017.

Subana dkk. 2000. Statistik Pendidikan. Bandung: Pustaka Setia.

Sugiyono. 2016. Metode Penelitian. Bandung: Alfabeta.

Syafri F. 2017. Kemampuan Representasi Matematis dan Kemampuan Pembuktian Matematika. Jurnal Edumath, Vol. 3 No. 1 (Online) 04 Agustus 2017.

Wahyudi T. 2015. Pelaksanaan Pendekatan Open-Ended dan Konvensional dalam Materi Sistem Persamaan Linear Dua Variabel ditinjau dari Kemampuan Awal Matematika Siswa Kelas VIII SMP Negeri 1 Pemangkat. Skripsi Sarjana pada IKIP-PGRI Pontianak: Tidak Diterbitkan. 